\title{
Tvorba projektu výrobnej haly a overenie layoutu výroby uplatnením simulačných prostriedkov
}

\author{
Marek Kliment ${ }^{1}$, Miriam Pekarčíkova ${ }^{1}$, Ladislav Rosocha ${ }^{1}$, Štefan Král ${ }^{2}$, \\ Tomáš Švantner ${ }^{2}$
}

${ }_{1}$ Technical University of Košice, Faculty of Mechanical Engineering, Institute of Management, Industrial and Digital Engineering

Park Komenskeho 9, Košice, Slovakia

marek.kliment@tuke.sk

miriam.pekarcikova@tuke.sk

ladislav.rosocha@tuke.sk

2 Slovak legal metrology

Hviezdoslavova 1124/31, Banská Bystrica, Slovakia

kral@slm.sk

svantner@slm.sk

\begin{abstract}
Anotácia: Mnoho podnikov rieši oblast' rozmiestnenia a umiestnenia výroby. Príspevok je zameraný na činnost' výrobnej spoločnosti, ktorá sa rozhodla vybudovat' nové výrobné priestory. $V$ týchto priestoroch chce zjednotit' výrobu, ktorá bola doposial' rozdelená na dve samostatné funkčné jednotky. Ide o strojársku spoločnost' pôsobiacu $v$ kusovej a malosériovej výrobe. Umiestnenie strojov je preto potrebné starostlivo zvážit' a výrobu sa snažit' urobit' čo najviac plynulou, ako pre zákazky malého aj väčšieho objemu. $V$ príspevku je spracovaný postup jednotlivých činností, ktoré budú zahŕňat' realizáciu myšlienky výstavby novej výrobnej haly od jej začiatku až po zahájenie výroby. $V$ stručnosti popisuje aj prostriedky ktoré boli využité pri projektovaní tejto haly.
\end{abstract}

\section{1 Úvod}

Ciel'om príspevku je vypracovat' návrh layoutu pre výrobný proces spoločnosti, ktorá plánuje výstavbu novej výrobnej haly. Spoločnost' touto investíciou plánuje optimalizovat' logistické procesy a náklady spojené $\mathrm{s}$ transportom výrobkov medzi viacerými prevádzkami. Pri spracovaní projektu a jeho postupností sme využili viacero softvérov. Postup realizácie projektu harmonogram postupnosti operácii bol spracovaný v MS Project. Následne v rámci riešenia pôdorysu a spôsobu výstavby haly boli uplatnené CAD programy a pre vypracovanie rozmiestnenia strojov $v$ už navrhnutej hale bol využitý simulačný softvér, ktorý nám zároveň umožnil aj prvýkrát vidiet' výrobný proces $v$ pohybe. Výroba vo výrobnej hale je zameraná na trieskové obrábanie strojárskych dielov. $\mathrm{V}$ hale sa budú nachádzat' obrábacie CNC stroje, zariadenia na prípravu delenie a vítanie materiálu. Pri súčiastkach kde sa vyžaduje povrchová úprava termochemickými procesmi ako sú alkalické čiernenie za tepla a zinočnaté fosfátovanie, bude súčast'ou výrobnej haly aj linka na tieto procesy. Spoločnost' sa podla požiadaviek zákazníkov a 
objednávok zaoberá aj klampiarskou činnost'ou a taktiež zváraním rôzneho druhu. Všetky tieto procesy budú súčast'ou jednej výrobnej jednotky zastrešenej $v$ jednom výrobnom komplexe.

\section{Fázy projektu a postup jeho realizácie}

Využili sme softvér MS Project pre spracovania potrebných krokov pre spracovanie celého projektu. Výstupom z tohto softvéru bol Gantov diagram postupnosti a náväznosti jednotlivých krokov realizácii. Jednotlivé kroky postupu, môžeme vidiet' v tabul'ke č. 1 a gantov diagram na obrázku č. 1 .

Tabulka 1 - Vstupné údaje pre realizáciu projektu v MS Project

\begin{tabular}{|c|c|c|c|}
\hline Úloha & Názov úlohy & $\begin{array}{l}\text { Bezprostredne predch. } \\
\text { činnost' }\end{array}$ & Odhad doby trvania \\
\hline 1. & Fáza zahájenia projektu & - & - \\
\hline 1.1 & Vypracovat́ návrh projektu & - & 1 mesiac \\
\hline 1.2 & Stanovenie rozsahu projektu & 1.1 & 1 týždeň \\
\hline 1.3 & Vypracovat' predbežný rozpočet & 1.2 & 2 týždne \\
\hline 1.4 & Zabezpečenie pozemku & 1.3 & 1 mesiac \\
\hline 1.5 & Vybavenie administratívnych záležitostí & 1.4 & 2 mesiace \\
\hline 1.6 & Zabezpečenie stavebnej firmy & 1.5 & 3 týždne \\
\hline 2. & Fáza investičná & - & - \\
\hline 2.1 & Projekt organizácie výstavby & 1.6 & 4 mesiace \\
\hline 2.2 & Nákup materiálu & 2.1 & 2 týždne \\
\hline 2.3 & Obstaranie dlhodobého majetku & 2.2 & 2 týždne \\
\hline 2.4 & Obstaranie krátkodobého majetku & 2.3 & 3 týždne \\
\hline 2.5 & Lay-out výrobnej haly & $2,1,2.2,2.3$ & 1 mesiac \\
\hline 3. & Fáza realizačná & - & - \\
\hline 3.1 & Vytvorenie nových pracovných miest & 2.5 & 1 týždeň \\
\hline 3.2 & Výber a príjem nových zamestnancov & 3.1 & 2 týždne \\
\hline 3.3 & Školenie zamestnancov & 3.2 & 2 týždne \\
\hline 3.4 & Inštalácia strojov & 2.5 & 1 týždeň \\
\hline 3.5 & Spustenie strojov & 3.4 & 1 týždeň \\
\hline 3.6 & Testovanie & 3.5 & 5 dní \\
\hline 3.7 & Kontrola & 3.6 & 6 dní \\
\hline 4. & Fáza ukončenia projektu & - & - \\
\hline 4.1 & Spustenie prevádzky & 3.7 & 1,2 týždne \\
\hline 4.2 & Vyhodnotenie projektu & 4.1 & 2,2 týždne \\
\hline 4.3 & Analýza vyhodnotenia & 4.2 & 1,2 týždne \\
\hline 4.4 & Ukončenie projektu & 4.3 & 6 dní \\
\hline
\end{tabular}




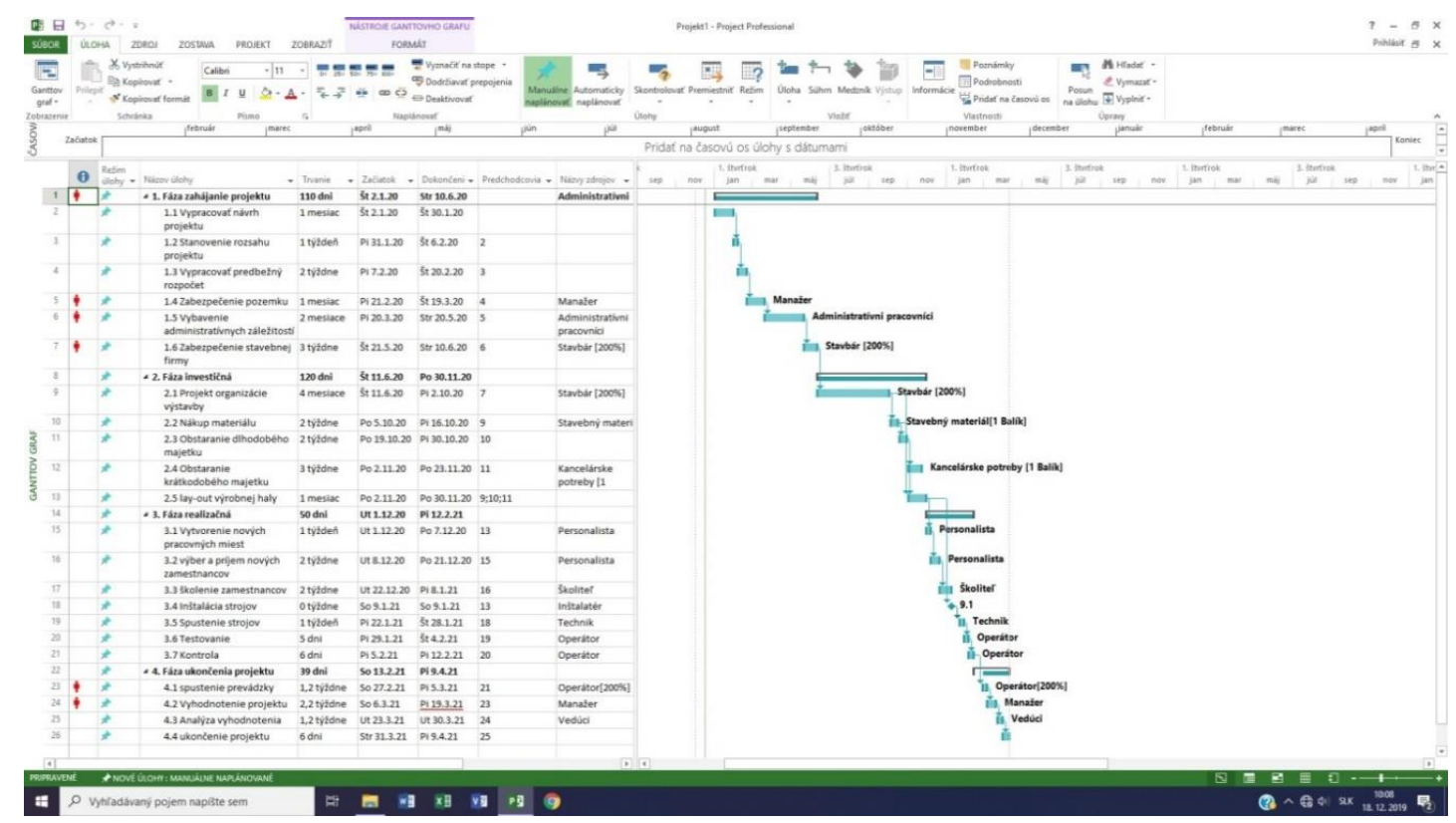

Obrázok 1 - Gantov diagram realizácie a nadväznosti v projekte

\subsection{Pôdorys výrobnej haly}

Ako je možné vidiet' $v$ tab. 1 bod 2.5 je posledným bodom $v$ investičnej fáze rozpracovaného projektu a pozostáva z vytvorenia layoutu výrobnej haly. Pre optimálne vytvorenie layoutu výrobnej haly, bol prevzatý pôdorys celej haly $s$ vypracovaného stavebného projektu. Pôdorys celej výrobnej haly môžeme vidiet' na obrázku č. 2.

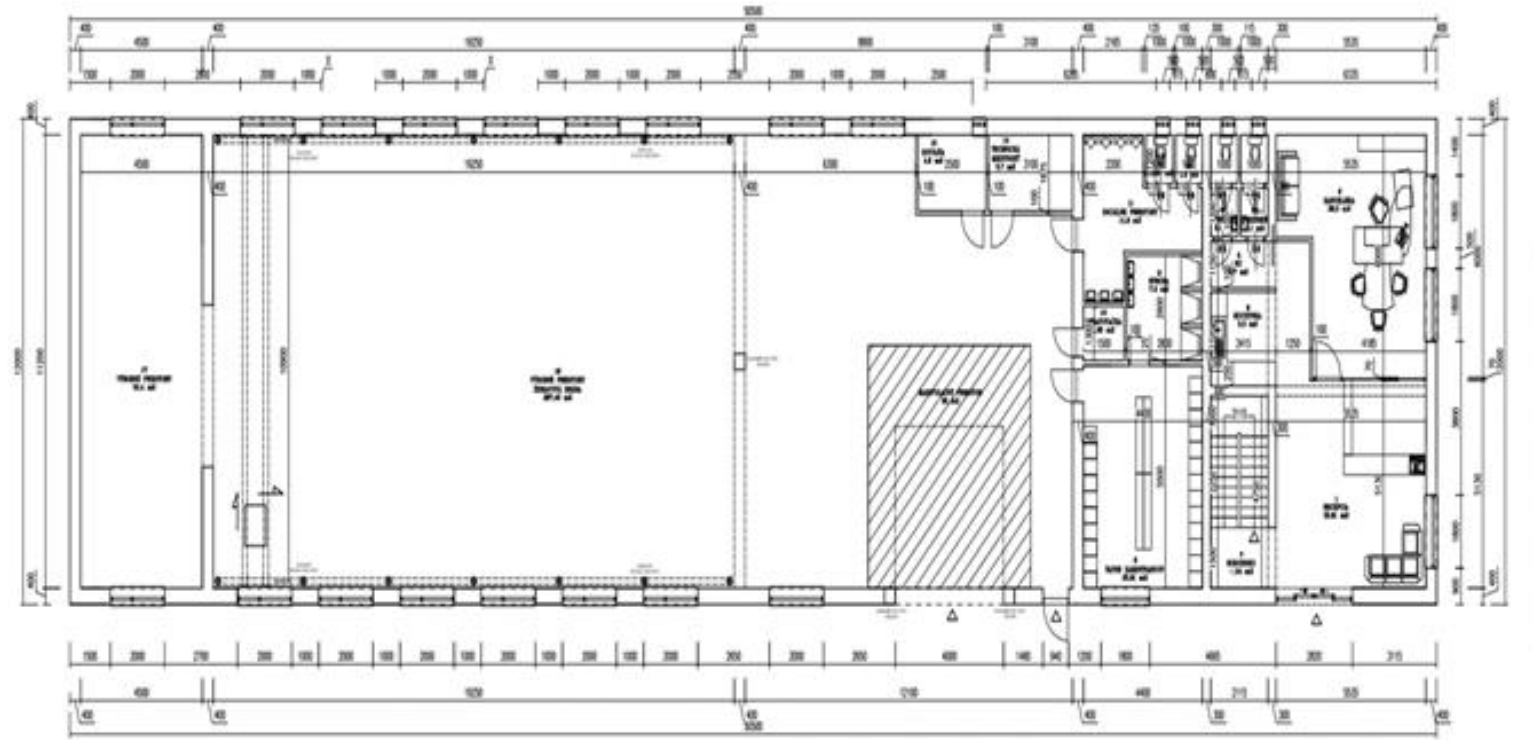

Obrázok 2 - Pôdorys výrobnej haly

Vo výrobnej hale sa budú nachádzat' tieto priestory: manipulačný priestor, výrobné priestory, recepcia, šatne pre zamestnancov, jedáleň, sociálne 
priestory, kancelárie, kuchynka, technická miestnost' a sprchy. Ako je vidno spoločnost' $v$ tomto priestore neplánuje mat' len výrobné priestory, ale aj priestory sociálneho zabezpečenia taktiež reprezentatívneho a administratívneho charakteru. Po výstavbe tejto haly by sa mala stat' novým klúčovým sídlom celej spoločnosti a súčasné výrobné priestory by sa mali využívat' len okrajovo, prípadne sa prenajat' na iné účely.

\subsection{Návrh rozmiestnenia zariadení}

Po vypracovaní a návrhu dizajnu celej haly sa pristúpilo $k$ riešeniu rozmiestenia zariadení, ktoré spoločnost' potrebuje pre svoju výrobnú činnost'. Ked'že produkcia je zameraná vo väčšej miere na malosériovú a kusovú výrobu bolo možné vypracovat' najprv model haly a následne do neho vkladat' zariadenia. Pri spracovaní modelu a pôdorysu haly sa dbalo nato aby boli priestorové možnosti predimenzované. Spoločnost' počíta do budúcna $s$ rozširovaním a inovovaním strojového zariadenia a preto $v$ súčasnej dobe priestorové možnosti radšej nadhodnotí a zariadenia bude podla svojich možností postupne dopíňat' a vymieňat'. Treba však pri riešení rozmiestnenia strojov vychádzat' aspoň $\mathrm{z}$ výrobného programu, ktorý $\mathrm{v}$ súčasnosti zastrešuje. Pre rozmiestnenie jednotlivých pracovísk sme si vybrali niekol'ko modelových a typových dielov, ktoré sa vyrábajú vo väčšom objeme, prípadne sa častejšie opakujú, či už rozmerovo ako aj typovo. Tento výber nám umožnil vytvorit' modelové situácie ako by bolo možné stroje usporiadat' pri ich osadzovaní. Pre overenie efektívnosti rozmiestnenia strojov sme využili simulačný model Tecnomatix Plant Simulation. Do tohto modulu sme si vložili pripravený pôdorysný model projektovanej haly a skúšali sme viaceré možné varianty ich rozmiestnenia a softvér nám pomohol vyhodnotit' ich viaceré varianty.

\subsubsection{Variant 1}

$\mathrm{Na}$ obrázku 3 môžeme vidiet' 3D spracovanie simulácie variantu 1 aj $\mathrm{s}$ celkovou štatistikou výrobného procesu. Výrobný proces prebieha $v$ dvoch pracovných zmenách. Na štatistickom vyhodnotení vidíme, že celková produkcia tohto variantu výroby je na hodnote $17,03 \%$ čo je pomerne nízka hodnota. Preto sme sa rozhodli vypracovat' d'alší variant rozmiestnenia tých istých zariadení $v$ tom istom priestore. 


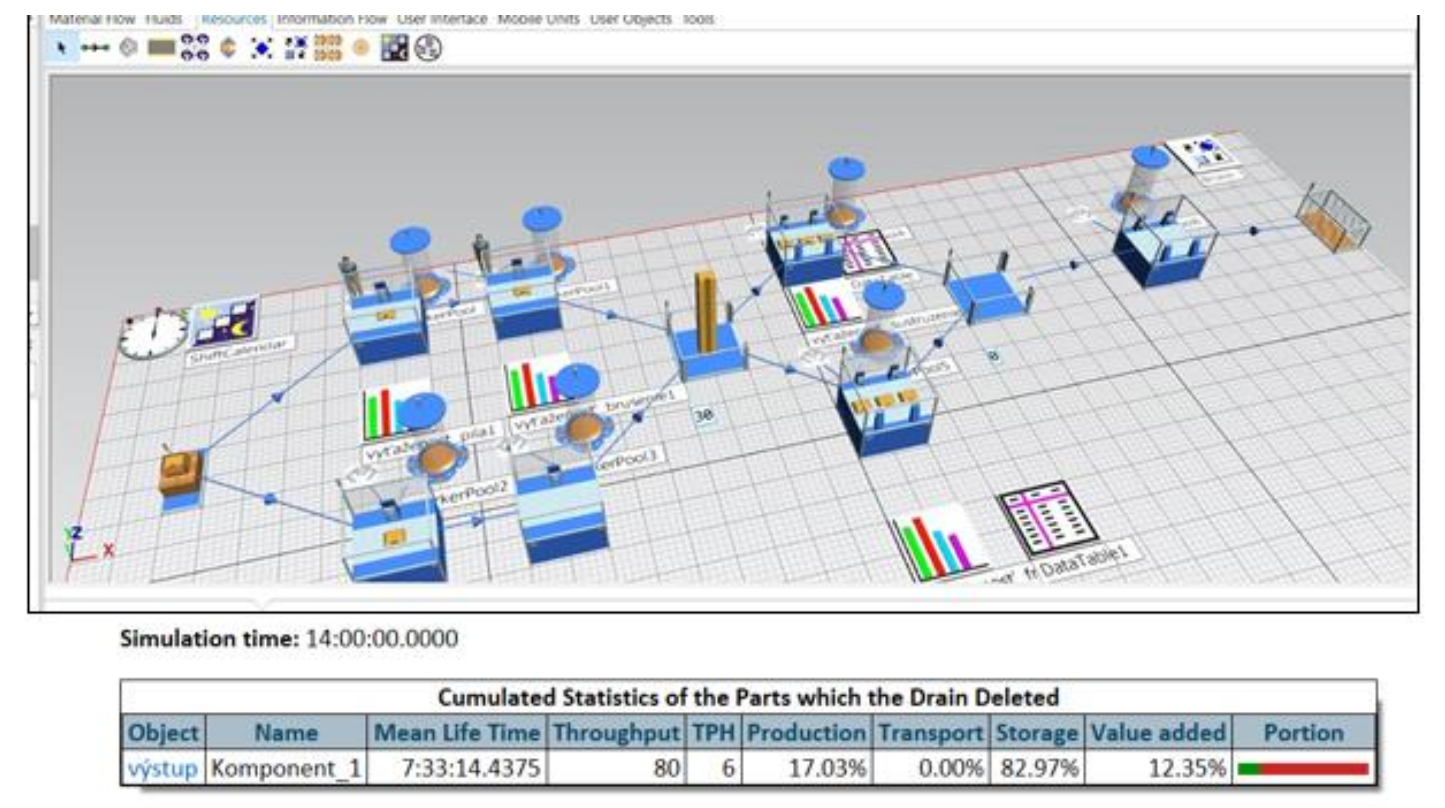

Obrázok 3 - 3D layout pre variantu 1 a štatistické zhodotenie

\subsubsection{Variant 2}

Pri spracovaní variantu č. 2 boli pracoviská usporiadané iným spôsobom, ako v prvom návrhu. $V$ tomto návrhu sme brali do úvahy aj možnost' uplatnit' na medzi objektovú dopravu vozíky, ktoré by medzi niektorými pracoviskami ulahčovali pohyb materiálu (obrázok č. 4). Pre vypracovanie návrhov na rozmiestnenie zariadení sme brali do úvahy výrobky, ktoré sa vo výrobnom procese najviac opakujú za posledných 5 rokov a ich výrobný proces je vel'mi podobný. Aj z tohto hladiska sa pri rozmiestňovaní pracoviská usporiadali, tak aby sa v čo najväčšej možnej miere eliminovala zbytočná doprava materiálu, medzi jednotlivými výrobnými stanicami.

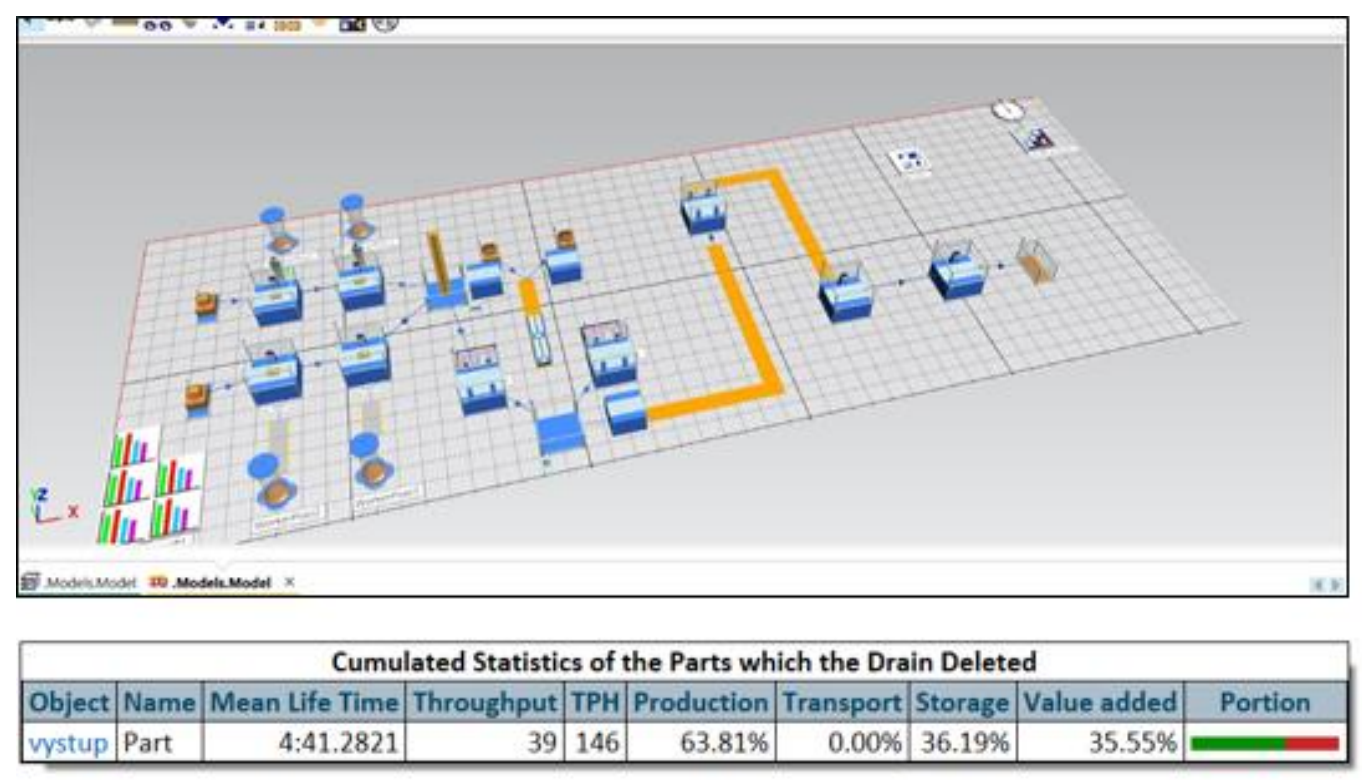

Obrázok 4 - 3D layout pre variantu 2 a štatistické zhodotenie 


\section{Záver}

Pri pohlade na štatistické vyhodnotenie Variantu č. 2 vidíme zlepšenie efektívnosti výrobného procesu. Jednotlivo sme vyhodnotili aj všetky stroje a zariadenia, ktoré vo výrobnom procese pracujú a navzájom sme ich porovnali, aby bolo názorne viditel'né, na ktorých pracoviskách došlo k zvýšeniu efektívnosti a kde sa parametre naopak zhoršili (tabul'ka č. 2)

Tabulka 2 - Porovnanie efektívnosti strojov v jednotlivých variantoch

\begin{tabular}{|l|l|l|l|}
\hline \multicolumn{3}{|c|}{ Uariant 1 } & \multicolumn{2}{c|}{ Variant 2 } \\
\hline Píla 1 & \multicolumn{1}{|c|}{ Vannost' strojov } \\
\hline Píla 2 & $2,38 \%$ & $58,33 \%$ & $55,95 \%$ \\
\hline Brúsenie 1 & $1,47 \%$ & $75,52 \%$ & $74,05 \%$ \\
\hline Brúsenie 2 & $1,57 \%$ & $85,94 \%$ & $84,37 \%$ \\
\hline Sústruženie & $2,90 \%$ & $98,44 \%$ & $95,54 \%$ \\
\hline Frézovanie & $92,12 \%$ & $59,54 \%$ & $35,58 \%$ \\
\hline Pourchoá úprava & $92,12 \%$ & $61,46 \%$ & $30,66 \%$ \\
\hline
\end{tabular}

Celková produkcia sa vo variante 2 zlepšila zo $17,03 \%$ na $63,81 \%$. pri operáciách sústruženie a frézovania však pri tomto variante produkcia klesla. Pokial' však prihliadame aj na plynulost' výrobného procesu, tak vidíme, že variant 2 sa javí ako výhodnejší. Na danom príklade je viditel'né, že uplatnenie simulácie, môžeme nájst' $v$ rôznych oblastiach životného cyklu výrobku

\section{Pod'akovanie}

Tento príspevok vznikol za podpory grantových projektov APVV-17-0258, APVV-19-0418, VEGA 1/0438/20 a KEGA 001TUKE-4/2020

\section{Použitá literatúra}

[1] EDL, M., LERHER, T., ROSI, B. Energy efficiency model for the mini-load automated storage and retrieval systems. International Journal of Advanced Manufacturing Technology, 2013, 1-19. ISSN: 0268-3768.

[2] STRAKA, M., KHOURI, S., ROSOVA, A., CAGANOVA, D., CULKOVA, K. Utilization of computer simulation for waste separation design as a logistics system. International Journal of Simulation Modelling, 2018, 17(4), 583-596.

[3] KŁOS, S. Implementation of the AHP method in ERP-based decision support systems for a new product development. Communications in Computer and Information Science, 2015. ISSN 1865-0929.

[4] CHROMJAKOVA, F., BOBAK, R., HRUSECKA, D. Production process stability - core assumption of Industry 4.0 concept. In: 5th International Conference on Manufacturing, Optimization, Industrial and Material Engineering, 2017, 143-154. 
[5] BUCKOVA, M., KRAJCOVIC, M., EDL, M. Computer simulation and optimization of transport distances of order picking processes. Procedia Engineering, 2017, 192, 69-74. doi: 10.1016/j.proeng.2017.06.012.

[6] FUSKO, M., BUCKOVA, M., GASO, M., KRAJCOVIC, M., DULINA, L., SKOKAN, R. Concept of Long-Term Sustainable Intralogistics in Plastic Recycling Factory. Sustainability, 2019, 11(23), $6750 . \quad$ doi: 10.3390/su11236750.

[7] FUSKO, M., RAKYTA, M., KRAJCOVIC, M., DULINA, L., GASO, M., GRZNAR, P. Basics of Designing Maintenance Processes in Industry 4.0. MM Science Journal, 2018, March, 2252-2259. ISSN 1803-1269.

[8] FEDORKO, G., MOLNÁR, V., HONUS, S., NERADILOVÁ, H., KAMPF, R. The application of simulation model of a milk run to identify the occurrence of failures. International Journal of Simulation Modelling, 2018, 17(3), 444457.

[9] MANLIG, F., SLAICHOVA, E., KOBLASA, F., VAVRUSKA, J. Innovation of business processes by means of computer-aided simulation. Novel Trends In Production Devices And Systems, Applied Mechanics and Materials, 2014, 474, 67-72. doi: 10.4028/www.scientific.net/AMM.474.67.

[10] MILLER, A., BUREŠ, M. New Approach to Industrial Engineering Education with the Help of Interactive Tools. Procedia - Social and Behavioral Sciences, 2015, 174, 3413-3419. doi.org/10.1016/j.sbspro.2015.01.1012.

[11] CMOREJ, T., PANDA, A., BARON, P., POOR, P., POLLAK, M. Surface finishing of 3d printed sample manufacturated by fused deposition modeling. MM Science Journal, 2017, 5, 1981-1985. doi: 10.17973/mmsj.2017_12_201753. 